\title{
Alla för alla. Jämlikhet, korruption och socialt förtroende
}

\author{
Bo Rothstein \& Eric M. Uslaner
}

SAMMANDRAG: Att socialt förtroende spelar en viktig roll har kommit att bli allmänt accepterat inom samhällsvetenskapen. I denna inflytelserika artikel undersöker Bo Rothstein och Eric M. Uslaner en förbisedd nyckelfaktor när det gäller att skapa generaliserat förtroende, nämligen jämlikhet. Att jämlikhet ignoreras i litteraturen om socialt kapital är egendomligt eftersom de länder som ligger bäst till när det gäller socialt förtroende också ligger bäst till när det gäller ekonomisk jämlikhet: de nordiska länderna, Nederländerna och Kanada. Samma länder har även ansträngt sig för att skapa jämlikhet i möjligheter, inte minst på områden som utbildning, arbetsmarknad och (på senare år) förhållandet mellan könen. De politiska konsekvenserna av författarnas forskning är att de låga nivåer av förtroende och socialt kapital som plågar många länder beror på att staten inte gör tillräckligt för att minska ojämlikheten. Samtidigt kan samhällen med lågt förtroende vara fångade $\mathrm{i}$ en så kallad social fälla där förtroendenivån är för låg för att kunna ligga till grund för den generella välfärdspolitik som skulle minska ojämlikheten.

NYCKELORD: socialt förtroende; socialt kapital; jämlikhet; korruption; social fälla.

PUBLICERINGSHISTORIK: Översättning av en av författarna bearbetad och reviderad version av artikeln "All for All. Equality, Corruption, and Social Trust", som ursprungligen publicerades i World Politics, volym 58, nr I 2005 (http://dx.doi.org/IO.I353/ wp.2006.0022).

во ROTHSTEIN är tillträdande professor i statsvetenskap vid Oxford University, där han kommer vara verksam vid Blavatnik School of Government samt vid Nuffield College. E-POSTADRESs: bo.rothstein@pol.gu.se

ERIC M. USLANER är professor i statsvetenskap vid University of Maryland. E-POSTADRESS: euslaner@umd.edu

FÖRSLAG PÅ KÄLLANGIVELSE:

Rothstein, Bo \& Eric M. Uslaner (2015) "Alla för alla. Jämlikhet, korruption och socialt förtroende", i Arkiv. Tidskrift för samhällsanalys, nr 4, s. I5I-185. DOI: http://dx.doi.org/IO.I3068/2000-6217.4.5

(C) Författarna/Arkiv förlag \& tidskrift 2015 (publicerad 2 december 20I5)

Artikeln distribueras enligt en upphovsrättslicens från Creative Commons: Erkännande-Ickekommersiell-IngaBearbetningar 3.0 Unported, som medger fri ickekommersiell användning och spridning i oförändrat skick så länge källan anges. 
Arkiv. Tidskrift för samhällsanalys är en sakkunniggranskad vetenskaplig tidskrift för samhällsvetenskap och historia. Samtliga artiklar publiceras fritt tillgängliga på:

www.tidskriftenarkiv.se

(beständig länk, DoI: http://dx.doi.org/IO.I3068/2000-62I7)

Den här artikeln finns tillgänglig i följande format:

PDF \& HTML: via beständig länk, DoI: http://dx.doi.org/IO.I3068/2000-62I7.4.5 EPUB: ingår i e-boksutgåva av numret, ISBN: 978 9I 79242725

TRYCK: ingår i bokutgåva av numret, ISBN: 978 9I 79242732

Grafisk utformning och sidnumrering är identisk i pdf och tryck.

Samtliga artiklar i nr 4 (2015) nås via beständig länk, DOI: http://dx.doi.org/IO.I3068/2000-6217.4

Arkiv. Tidskrift för sambällsanalys ISSN: 2000-62I7 (för elektronisk resurs)

ISSN: 2000-6225 (för tryckta nummer)

ges ut av

Stiftelsen Arkiv för främjande och spridning av samhällsvetenskaplig och historisk forskning

genom

Arkiv förlag \& tidskrift

Box 1559

SE-22I OI Lund

BESÖк: L Gråbrödersg $3 \mathrm{c}$, ipg

TEL: O46-I3 3920

ARKIV FÖRLAG: arkiv@arkiv.nu·www.arkiv.nu

TIDSKRIFTEN ARKIV: red@tidskriftenarkiv.se · www.tidskriftenarkiv.se

ANSVARIg UTGIVARE \& CHEFREDAKTÖR: Sven Hort

ADMINistrativ RedAKTÖr: David Lindberg

RedAKtörer: Paavo Bergman, Lisa Kings, Zhanna Kravchenko 


\section{Alla för alla. \\ Jämlikhet, korruption \\ och socialt förtroende}

\section{BO ROTHSTEIN \& ERIC M. USLANER}

Att socialt förtroende spelar en viktig roll har kommit att bli allmänt accepterat inom samhällsvetenskapen. Ett skäl till intresset för socialt förtroende är att det, som framgår av flera undersökningar, korrelerar med en rad andra förhållanden som är högst eftersträvansvärda. Människor som anser att man i allmänhet kan lita på de flesta andra människor i samhället är mer benägna att hysa en positiv uppfattning om samhällets demokratiska institutioner, att delta mer i politiken och att vara mer aktiva i frivilligorganisationer. De skänker också mer till välgörenhet och är mer toleranta mot minoriteter och mot människor som är annorlunda än de själva. Människor som litar på andra har också en tendens att vara mer optimistiska om sin förmåga att påverka sina livschanser och, inte minst viktigt, att vara mer tillfreds med hur deras liv utvecklar sig (Helliwell 2002; Uslaner 2002; Delhey \& Newton 2003).

Vi ser samma positiva mönster på den samhälleliga nivån. Städer, regioner och länder med mer förtroendefulla människor har sannolikt bättre fungerande demokratiska institutioner, öppnare ekonomier, större ekonomisk tillväxt och mindre brottslighet och korruption (Beugelsdijk, de Groot \& van Schaik 2004; Putnam 1996; Zak \& Knack 200I). På både den individuella och den samhälleliga nivån tycks många saker som

Artikeln är en av författarna bearbetad och reviderad version av "All for All. Equality, Corruption, and Social Trust", som ursprungligen publicerades i World Politics, volym 58, nr I 2005 (http://dx.doi.org/IO.I353/wp.2006.0022). 
är normativt eftersträvansvärda hänga ihop med socialt förtroende. Kausalitet är förvisso något annat än statistisk korrelation, men eftersom så många korrelationer pekar i samma riktning har samhällsvetare från olika discipliner börjat intressera sig för förtroende. ${ }^{\mathrm{I}}$

Förtroende varierar mellan nationer. I Norge, Danmark och Nederländerna tror ungefär 60 procent av befolkningen att man kan lita på de flesta andra människor, medan det i Brasilien, Filippinerna och Turkiet bara är Io procent som litar på andra. ${ }^{2}$ Delhey och Newton menar att när människor svarar att de tycker att man kan lita på de flesta andra människor, kan detta tolkas som deras bedömning av samhällets moraliska standard (Delhey \& Newton 2004). Det betyder att förtroende speglar en känsla av social solidaritet, att de är övertygade om att de olika grupperna i samhället har gemensamma mål, och att man är skyldig att erbjuda dem som har små resurser möjligheter. Vi ser detta samband mellan socialt förtroende och solidaritet i de goda gärningar som de förtroendefulla utför (välgörenhet, frivilligarbete) och i de politiska åtgärder som förtroendefulla samhällen vidtar för att hjälpa de resurssvaga (Uslaner 2002, kap. 7).

Vi hävdar att socialt förtroende framkallas av två olika men med varandra förbundna typer av jämlikhet, nämligen ekonomisk jämlikhet och jämlikhet i möjligheter. Detta argument får viktiga konsekvenser för den statliga politiken, eftersom en generell socialpolitik är effektivare än selektiva politiska åtgärder när det gäller att skapa båda typerna av jämlikhet och därmed socialt förtroende. Men vi hyser en något pessimistisk uppfattning om de politiska möjligheterna att öka jämlikheten genom att driva en generell socialpolitik i utvecklingsländer och postsocialistiska länder. Eftersom det sociala förtroendet är ett mått på hur människor bedömer den moraliska nivån i sitt samhälle, finns det ingen större anledning att tro att länder med lågt socialt förtroende kommer att genomdriva generella sociala program, just därför att sådana program måste bygga på

I. Antalet artiklar publicerade i vetenskapliga tidskrifter med trust ("förtroende") som nyckelord eller i sin sammanfattning visar en ökning från I29 till I 956 från I990 till 2005 . Lägger man growth till trust ökar antalet från I artikel till 42, vilket tyder på ett starkt intresse från samhällsvetares sida att använda detta begrepp (från ISI Web of Knowledge, numera Web of Science).

2. World Values Survey, http://www.worldvaluessurvey.org/wvs.jsp. 
en allmän politisk föreställning om att de olika grupperna i samhället också har gemensamma mål. Länder som redan har hög ojämlikhet och ett korrupt styre är mindre benägna att införa generella sociala program. Sådana program ökar det sociala förtroendet på tre sätt. För det första är de mer omfördelande än inkomstprövade program och skapar alltså större ekonomisk jämlikhet. För det andra ökar de känslan av "jämlikhet i möjligheter" inom befolkningen eftersom de bygger på principen om lika behandling och minimerar det byråkratiska godtycket (Rothstein 1994). För det tredje förstärker inkomstprövade program klass- och ofta även rasmotsättningarna inom ett samhälle - och leder alltså till ett mindre generaliserat förtroende och ett större förtroende inom grupper. Generella program förstärker däremot den sociala solidariteten och föreställningen om en social gemenskap bland medborgarna.

Skälet till att länder med stor (eller växande) ojämlikhet är mindre benägna att införa generella program är att sådana program vanligen bygger på föreställningen att alla grupper i samhället, oberoende av social och ekonomisk ställning, är sammanlänkade. Människor kommer bara att förlägga sin tillit till den egna gruppen eller klassen, och de som har mindre resurser kommer att tro att de inte har samma möjligheter som människor med större resurser. De är övertygade om att de rika har nått sina positioner genom orättvis fördelning av förmåner. Människor med mindre resurser kommer alltså att kräva en radikal omfördelning från de rika till de fattiga och kommer att försöka hindra de mer resursrika från att få del av statliga bidrag. Det ironiska är att när man måste bevisa att man är tillräckligt fattig för att få statliga bidrag, skapar systemet förbittring och misstro snarare än känsla av makt och självförtroende. Dessa "inkomstprövade" förmåner bidrar alltså inte till att minska ojämlikheten och ökar inte heller förtroendet för andra medborgare. Politiska åtgärder med syfte att minska fattigdomen skapar $i$ stället en ojämlikhetsfälla, mindre framtidsoptimism, mindre förtroende för andra, större identifikation med den egna gruppen och bestående orättvisor i förmögenhetsfördelningen.

Man kunde tro att representanter för låginkomstgrupper i samhällen med stor ojämlikhet förespråkar generella sociala program eftersom de inser att dessa kommer att vara till störst nytta för deras grupper. Men 
detta har historiskt sällan varit fallet (Katz 1999). För det första är logiken som ligger bakom det faktum att generella program är mer omfördelande än program som inriktas specifikt på "de fattiga" komplex. Många välkända politiska filosofer som har vågat kasta sig in i diskussionen om social rättvisa har varit oförmögna att förstå denna logik (se t.ex. Rothstein 1994, kap. 6). Eftersom de omfördelande effekterna av generella sociala program är svåra att förklara blir det också svårt att få stöd för dem från underprivilegierade grupper. För det andra gynnar generella program även mer välbärgade grupper. I ett samhälle med stora ojämlikheter blir det därför inte så lätt för dem som talar för underprivilegierade grupper att övertyga sina anhängare om att knappa offentliga resurser också ska gå till medelklassen.

$\mathrm{Vi}$ påstår att rötterna till ett generaliserat förtroende ligger i en rättvisare fördelning av resurser och möjligheter i ett samhälle. Länder som har en historia av större jämlikhet, till exempel de nordiska länderna, har också en historia av mindre förtryckande och mer hederliga regeringar. Större jämlikhet och mindre korruption leder till mer inklusiva (generella) välfärdsprogram och till större generaliserat förtroende. Vi påstår också att ojämlikheten befinner sig i början av orsakskedjan. Vi betraktar fördelningen av resurser och möjligheter i ett samhälle som nyckeln till de andra delarna av vår berättelse - låg korruption, generaliserat förtroende och sociala välfärdsregimer.

Jämlikhet och låg korruption befinner sig alltså i början av vår orsakskedja. Båda krävs för att etablera förtroende och den generella socialpolitik som leder till större jämlikhet och sammanhållning i samhället. De förstärkande effekter som ojämlikhet och hederlighet får på förtroende och socialpolitik - och "återkopplingen" till större förtroende och mindre ojämlikhet - leder till en positiv jämvikt för samhällen som vidtar åtgärder för att införa en generell välfärdspolitik. Men de leder till en negativ jämvikt - en ojämlikhetsfälla - för länder med stor eller växande ojämlikhet och en korrupt förvaltning. Eftersom jämlikhet och låg korruption kommer först gör de ömsesidiga effekter som vi förutsätter det (i bästa fall) svårt för länder att undkomma ojämlikhetsfällan.

Vi stöder våra påståenden med hjälp av en rad metoder. För det första visar vi genom en komparativ statistisk analys att ojämlikhet är en 
nyckelfaktor när det gäller att skapa generaliserat förtroende, men att förtroendet inte har någon direkt effekt på ojämlikheten; snarare inleds orsakskedjan med ojämlikheten. För det andra undersöker vi också sambanden mellan låg korruption, förtroende och politiska beslut genom att sammanfatta forskningsläget på korruptionsområdet snarare än att presentera nya empiriska analyser. För det tredje undersöker vi hur en historia av relativt större jämlikhet och låg korruption lade grunden för den generella välfärdspolitiken i Sverige, och hur denna politik bidrog till att förstärka en känsla av social solidaritet. För det fjärde visar vi hur inkomstprövade bidrag leder till mindre förtroende i ett samhälle som har varit fientligt inställt till generella politiska åtgärder, nämligen USA. Slutligen utvecklar vi med hjälp av ett brett spektrum av forskningsresultat vår argumentering för att ursprungligen egalitära samhällen sannolikt kommer att förbli egalitära, och för att det är svårt för ojämlika samhällen att utveckla generaliserat förtroende, hederligt regeringsstyre, generell socialpolitik och större jämlikhet.

\section{Förtroende kontra förtroende: teorin}

Det generaliserade förtroendet förenar oss med människor som är olika oss själva. Det står i kontrast till det partikulariserade förtroendet, där människor bara litar på sin egen grupp. Generaliserat förtroende speglar ett band som förenar människor i hela samhället och i alla ekonomiska och etniska grupper och religioner. Partikulärt förtroende speglar sociala spänningar, där varje grupp i ett samhälle ser till sina egna intressen och inte litar så mycket på andra människors goda avsikter. Människor med partikulärt förtroende kan vara lika engagerade i medborgerligt liv som människor med generaliserat förtroende, men de kommer att begränsa sina aktiviteter och goda gärningar till människor av deras eget slag.

Generaliserat förtroende både bygger på en grund av ekonomisk och social jämlikhet och bidrar till utvecklingen av ett mer jämlikt samhälle. När det sociala förtroendet förenar oss med människor som är olika oss själva speglar det en omsorg om andra, särskilt människor som har blivit diskriminerade och därför har mindre resurser (Uslaner 2002). I samhällen där ojämlikheten är stor och det inte görs så stora (eller effektiva) politiska 
ansträngningar för att öka jämlikheten i möjligheter saknas omsorgen om människor från andra bakgrunder. De rika och de fattiga i ett land med en mycket ojämn förmögenhetsfördelning, till exempel Brasilien, kan leva nära varandra utan att deras liv korsar varandra. Deras barn går i olika skolor, de använder olika sjukvårdsinrättningar, och i många fall har de fattiga inte råd med någotdera. De rika skyddas av både polisen och privata vaktstyrkor, medan de fattiga ser dessa grupper som sina naturliga fiender. I sådana samhällen har varken de rika eller de fattiga någon känsla av att de har något gemensamt. Det generaliserade förtroendet är lågt medan det partikulära är högt. Varje grupp ser till sina egna intressen och anser att den andra gruppens krav hotar dess egen välfärd. Samhället ses som ett nollsummespel mellan stridande grupper.

Den statliga politiken har stor inverkan på den ekonomiska jämlikheten (Gustafsson \& Johansson 1999; Atkinson 1999; Korpi \& Palme 2003; Gottschalk \& Smeeding 1997). Generella sociala program som riktar sig till alla (eller till mycket breda grupper), som i de skandinaviska länderna, främjar en mer rättvis förmögenhetsfördelning och större jämlikhet i möjligheter på områden som utbildning och arbetsmarknad (Korpi \& Palme 1998). Båda typerna av jämlikhet leder till en större känsla av social solidaritet, vilket framkallar ett generaliserat förtroende. Det generaliserade förtroendet ligger i sin tur åtminstone delvis till grund för politiska åtgärder (till exempel generella bidrag) som leder till större jämlikhet. Därmed inte sagt att det råder ett enkelriktat förhållande mellan oberoende variabler (politiska åtgärder) och beroende variabler (normer), eftersom vi är medvetna om att det finns "återkopplingsmekanismer" och "växande utbyte" mellan dessa variabler (Pierson 2000). Vi vill i stället fånga logiken i dessa orsaksmekanismers sätt att kombinera variablerna över tiden och förklara vad det är för faktorer som får denna onda eller goda cirkel att utvecklas som den gör.

\section{Varför har vissa länder mer socialt förtroende än andra?}

Varför har vissa länder mer förtroendefulla medborgare än andra? I den oftast åberopade förklaringen lägger man fokus på deltagande i frivilligorganisationer, men den förklaringen har inte fått stöd i empiriska 
undersökningar. Till exempel i en stor empirisk studie som täcker sextio länder blir slutsatsen denna: "Vad som kanske är viktigast och mest överraskande är att inget av de fyra måtten på frivillig aktivitet klarade det statistiska testet, trots den betydelse som de tillskrivs i mycket av det som har skrivits på området, från de Tocqueville och framåt" (Delhey $\&$ Newton 2004, s. 27).

Vi hävdar i vår alternativa förklaring att den viktigaste faktorn som ligger bakom förtroende är graden av jämlikhet i ett samhälle. Vi utvecklar jämlikhet teoretiskt i två dimensioner: ekonomisk jämlikhet och jämlikhet i möjligheter. Jämlikhet i resultat är relativt enkelt att förstå, om än inte att mäta: Hur rättvist är resurserna fördelade i ett samhälle? Det finns många olika mått på ojämlikhet i litteraturen; vi använder det mest använda, Gini-koefficienten, eftersom det finns tillgängligt för det största antalet länder.

Jämlikhet i möjligheter handlar om de förutsättningar att vinna ekonomisk framgång som människor ser framför sig, även om samhället för ögonblicket är starkt stratifierat. Även i fall där regeringar inte omedelbart kan minska ojämlikheten kan de vidta åtgärder som ger större möjligheter till ekonomisk jämlikhet. Att exempelvis satsa på generella utbildningsprogram ger löften om större jämlikhet i resultat eftersom högre utbildning skapar förutsättningar för ekonomiska framsteg. Utbildning är också en av de viktigaste faktorerna bakom generaliserat förtroende (Brehm \& Rahn 1997; Uslaner 2002).

Föreställningen om gemenskap är starkt beroende av båda typerna av jämlikhet. Seligman menar att förtroende inte kan uppstå i hierarkiska samhällen ( 1997, s. 36-37, 4I). I sådana samhällen råder en sträng social ordning präglad av en strikt klassindelning som består över generationerna. Feodala system och samhällen baserade på kaster dikterar vad människor kan och inte kan göra beroende på social bakgrund. Där ekonomiska resurser är stratifierade - eller när människor tror att andra människor har orättvisa fördelar - kommer det inte att utvecklas något förtroende, och nyttan av förtroende, inklusive politiska åtgärder som ytterligare minskar ojämlikheten, kommer att vara bedräglig. Antagandet att andra människor delar ens föreställningar är kontraintuitiv eftersom en strikt klassindelning gör det osannolikt att människor delar värderingar över klassgränserna. 
Att båda dimensionerna av jämlikhet ignoreras i litteraturen om socialt förtroende är egendomligt av flera skäl. Ett skäl är att de länder som ligger bäst till när det gäller socialt förtroende också ligger bäst till när det gäller ekonomisk jämlikhet: de nordiska länderna, Nederländerna och Kanada. Det finns ett starkt samband mellan förtroende och ojämlikhet i länder utan ett arv av kommunistiskt styre. ${ }^{3}$ I figur I visar vi sambandet mellan förtroende aggregerat på nationell nivå och DeiningerSquires mått på ekonomisk ojämlikhet för fyrtiotre länder på I990-talet. Sambandet är relativt starkt: $r^{2}=0,391$. Använder vi de nyare Galbraithmåtten på ojämlikhet minskar $\mathrm{N}$ till 32 men $\mathrm{r}^{2}$ ökar till 0,582 . Dessa resultat är alltså inte begränsade till en särskild samling data. Även över tid, från 1960 till 2002, är sambandet mellan förtroende och ekonomisk jämlikhet starkt i till exempel USA: $r^{2}=0,592(N=32)$. Den ekonomiska ojämlikhetens effekter på förtroendet är bestående, vilket inte är särskilt överraskande eftersom ingen av dem är så lätt att förändra. 1963 års ojämlikhetsindex visar lika starkt (eller kanske ännu starkare) samband med förtroende som 1996 års nivå av ekonomisk stratifiering.

Vi utvecklar dessa resultat i tabell $\mathrm{I}$, där vi återger en del av den ekvationsmodell som Uslaner kommer fram till i en studie av korruption (2005). Ekvationerna för förtroende och ojämlikhet säger samma sak som en enklare tvåekvationsmodell (med mycket färre fall) i Uslaner: ojämlikhet är en stark prediktor för generaliserat förtroende, men förtroende har ingen direkt effekt på ojämlikhet (2002, s. 233-236). Riktningen går från ojämlikhet till förtroende, men inte tvärtom. Dessa resultat begränsar sig inte till en enda uppsättning av modeller. Ojämlikhet är den faktor som visar det starkaste sambandet med förtroende över tiden $i$ USA och i de amerikanska delstaterna (Uslaner 2002, s. I86-I89; Uslaner \& Brown 2005).

När vi rör oss från den låga ojämlikhetsnivån i Belgien till den mycket höga nivån i Sydafrika sjunker förtroendet med 23 procent. Samma siffra kommer vi fram till om vi rör oss från den låga förtroendenivån i Serbien, Tjeckien, Sydkorea, Spanien eller Bulgarien till Nederländerna och Kanada. Men det finns naturligtvis också andra faktorer

3. För en förklaring till att vi utesluter länder med ett arv av kommunism, se Uslaner 2002, s. 228-230. 
Figur I. Förtroende för människor och ekonomisk ojämlikhet (tidigare och nuvarande kommunistländer uteslutna)

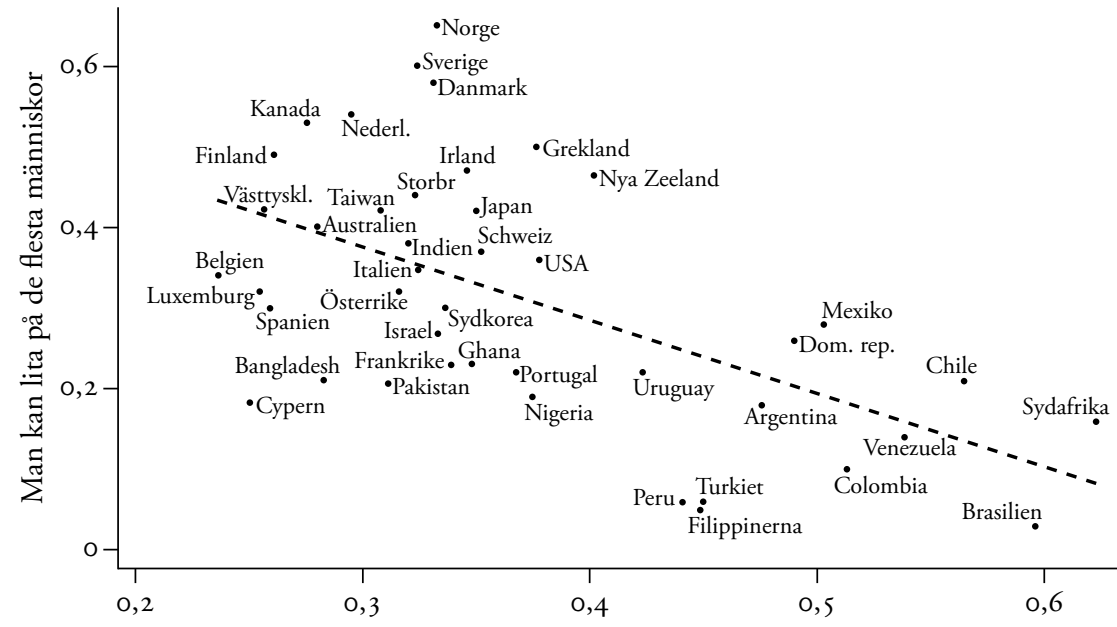

Gini-koefficient för ekonomisk ojämlikhet Korrelation, $\mathrm{r}^{2}=0,39 \mathrm{I}, \mathrm{N}=43$

som inverkar på förtroendet: protestantiska länder har högre förtroendenivåer, medan tidigare kommunistiska länder som har upplevt inbördeskrig har lägre.

Modellen i tabell $\mathrm{r}$ är en del av en ekvationsmodell skattad av Uslaner (2005) som inkluderar inte bara förtroende och ojämlikhet utan även korruption (Transparency International's Corruption Perceptions Index för 2004), landets regleringsgrad (från Världsbankens governanceindikatorer), landets ekonomiska stabilitet (från International Country Risk Guide) och ett index för regeringens effektivitet (härlett från en faktoranalys av sex indikatorer på nationell nivå från 2004 års World Economic Forum's Executive Opinion Survey). Modellen skattades genom minsta kvadratmetoden.

Modellen i tabell I visar också att länder som har upplevt inbördeskrig har lägre grad av socialt förtroende, liksom också tidigare kommunistiska länder. Kommunismen gjorde det svårt att lita på någon utanför (och ibland till och med inom) den egna familjen. Protestantiska sam- 
ARKIV $\mid$ NR 4

Tabell I. Förtroende- och ojämlikhetsekvationer frän simultanmodell av förtroende, ojämlikhet och korruption

Förtroendeekvation

\begin{tabular}{lccr}
\hline Ekonomisk ojämlikhet (Gini-koefficient) & $-0,46 \mathrm{I}^{* * *}$ & $0, \mathrm{I} 95$ & $-2,36$ \\
Inbördeskrig & $-0,086^{* * * *}$ & 0,025 & $-3,4 \mathrm{I}$ \\
Protestantisk befolkningsandel I980 & $0, \mathrm{I} 74^{* * *}$ & 0,063 & 2,79 \\
Tidigare kommunistland & $-0,09 \mathrm{I}^{* *}$ & 0,045 & $-2,0 \mathrm{I}$ \\
Regeringens effektivitet & 0,028 & 0,024 & $\mathrm{I}, \mathrm{I} 8$ \\
Konstant & $0,479^{* * * *}$ & 0,077 & $6, \mathrm{I} 9$ \\
Ojämlikhetsekvation & & & \\
\hline Förtroende & & & \\
Korruption & $-0, \mathrm{I} 52$ & $0, \mathrm{I} 87$ & $-0,8 \mathrm{I}$ \\
Tidigare kommunistland & $-0,028^{* * *}$ & 0,009 & $-3,23$ \\
Protestantisk befolkningsandel I980 & $-0, \mathrm{I} 66^{* * * *}$ & 0,025 & $-6,59$ \\
Muslimsk befolkningsandel & $0, \mathrm{I} 23$ & 0,052 & 2,38 \\
Konstant & $-0,00 \mathrm{I}^{* * * *}$ & 0,000 & $-3,77$ \\
& $0,583^{* * * *}$ & 0,035 & $\mathrm{I} 6,77$
\end{tabular}

\begin{tabular}{lcccc} 
Ekvation & $r^{2}$ & SEE & $m$ & F-statistik \\
\hline Förtroende & 0,664 & $0,08 \mathrm{I}$ & 0,296 & $2 \mathrm{I}, 35$ \\
Ojämlikhet (Gini-koefficient) & 0,534 & 0,072 & 0,360 & $\mathrm{I} 2,34$
\end{tabular}

$\mathrm{p}<0, \mathrm{IO} ;{ }^{* *} \mathrm{p}<0,05 ;^{* * *} \mathrm{p}<0, \mathrm{OI} ;{ }^{* * * *} \mathrm{p}<0,000 \mathrm{I}$ (alla tester one-tailed utom för konstanter); $\mathrm{N}=63$.

hällen, som har mer individualistiska politiska kulturer, har också högre socialt förtroende. De kollektivistiska och hierarkiska kulturerna i katolska samhällen leder till mindre generaliserat förtroende (och mer gruppförtroende). Effektiva regeringar leder inte till större förtroende bland medborgarna. ${ }^{4}$ Korruption leder till större ojämlikhet, medan tidigare kommunistiska länder och länder med stora muslimska befolkningar har mindre ojämlikhet. Bristen på marknader i tidigare kommunistiska länder har lett till större inkomstutjämning; inom islam betonar man jämlikhet. Vi förväntade oss att rika protestantiska länder också skulle ha mindre ojämlikhet, men de har det inte, och koefficienten tyder på att de till och med kan vara ännu mer ojämlika.

4. För måtten på detta, se Uslaner 2005 . 
Jong-Sung You finner i en studie belägg för att det finns en koppling mellan ojämlikhet och förtroende även på individnivå (You 2005, kap. 5, särskilt s. I65). Han skattar hierarkiska lineära modeller för generaliserat förtroende i åttio länder med hjälp av 1995-1997 och 1999-200I års World Values Surveys. Hans modeller visar att förtroendet är lägre i länder med högre nivåer av ojämlikhet. Han demonstrerar genom ett kreativt bruk av aggregerade index för inkomstfördelning att skevhet i fördelningen av inkomster kraftigt minskar förtroendet, medan spridning av fördelningen inte påverkar förtroendet $\mathrm{i}$ någon större utsträckning. Hur mycket man tjänar är inte avgörande för förtroendet, men när inkomstfördelningen är starkt ojämlik minskar den sociala solidariteten.

De nordiska länderna har ansträngt sig mycket för att skapa jämlikhet i möjligheter, inte minst på områden som utbildning, arbetsmarknad och (på senare år) förhållandet mellan könen. Man kan förvisso diskutera om dessa åtgärder har varit så framgångsrika som man hoppats, men regeringarna i dessa länder har varit jämförelsevis ambitiösa i sin satsning på dessa program (Huber \& Stephens 200I). Vi menar att regeringarna genom att inrätta generella sociala program sänder signaler till medborgarna som är viktiga för skapandet av solidaritet och socialt förtroende.

Det finns goda teoretiska skäl till att båda typerna av jämlikhet och socialt förtroende står i ett orsaksförhållande till varandra. För det första blir det mindre meningsfullt att hysa optimism om framtiden (som är en central faktor bakom socialt förtroende) när det råder större ekonomisk ojämlikhet. När människor tycker att framtiden ser ljus ut verkar det mindre riskfyllt att lita på främlingar (Uslaner 2002, kap. 2 och 4). De mindre lyckosamma har mindre anledning att vara optimistiska om sin (eller barnens) framtid om de upplever att samhället inte ger dem lika möjligheter, särskilt på områden som utbildning och arbetsmarknad. Människor som finns längst ner på inkomstskalan eller minoriteter som känner sig diskriminerade kommer inte att tro på möjligheten att få del i samhällets rikedomar. Det är hur bra landet presterar kollektivt snarare än hur någon presterar individuellt som leder till förändringar i det generaliserade förtroendet (Kinder \& Kiewiet 1979).

För det andra spelar fördelningen av resurser och möjligheter en central roll när det gäller att uppamma en känsla bland människor att de har 
något gemensamt och delar vissa grundläggande värderingar. När resurser och möjligheter är mer jämlikt fördelade, är människor mer benägna att uppfatta det som att de har gemensamma intressen med andra och är en del av en större social ordning. Om det finns stora skevheter i förmögenhetsfördelningen eller i möjligheterna att förbättra sina chanser i livet kan människor i båda ändar av spektrumet tycka att de har föga gemensamt med andra. I starkt ojämlika samhällen håller människor sig gärna till sin egen grupp. Upplevelser av orättvisa kommer att förstärka negativa stereotyper av andra grupper och göra det svårare att skapa socialt förtroende (Boix \& Posner 1998).

Att ojämlikhet inte förekommer i litteraturen om socialt kapital och socialt förtroende är något av ett mysterium. Även om Putnam pekar på vikten av ekonomisk ojämlikhet i sin analys av det minskande sociala kapitalet i USA nämns den inte i hans slutsatser om vad som "dödade samhällsengagemanget" (Putnam 2006, s. 386 ff. och kap. I5; Rothstein 2000). Inget av hans sju recept på politiska åtgärder för att öka det sociala kapitalet i USA tar upp någon form av ojämlikhet (Putnam 2006, kap. 24). Detta är så mycket mer överraskande som den minskning av det sociala kapitalet som Putnam avslöjar i USA sedan I970-talet tycks vara misstänkt förbunden i tiden med en dramatisk ökning av den ekonomiska ojämlikheten (Neckerman 2004; jfr Scocpol 2003). Ojämlikheten har ökat i USA sedan 1980-talet i takt med att den amerikanska välfärdsstaten har krympt (Hacker 2004).

Samma egendomliga utelämnande kan man se i Russell Sage Foundations stora projekt om förtroende: inget av de fyrtiofyra kapitlen i de tre redigerade volymerna handlar om ekonomisk ojämlikhet, och i ingen av volymerna förekommer jämlikhet eller ojämlikhet som uppslagsord i registret (Braithwaite \& Levi red. 1998; Cook red. 200I; Ostrom \& Walker red. 2003). Det gäller också för de tre monografier som projektet har gett upphov till (Hardin 2002; Tyler \& Huo 2002; Cook, Hardin \& Levi 2005). Medan statsvetare och sociologer i stort sett har bortsett från den betydelse som jämlikheten har för skapandet av förtroende, har ekonomer varit mer intresserade. Stephen Knack och Paul Zak vid Världsbanken har dragit slutsatsen att omfördelning är ett viktigt politiskt alternativ genom vilket regeringar kan försöka öka det sociala förtroendet 
(men de tillägger, på ett sätt som verkar vara obligatoriskt för ekonomer, att de oroar sig för de ekonomiska ineffektiviteter som omfördelningen kan leda till; se Knack \& Zak 2003). Åtskilliga regeringar och intresseorganisationer har använt forskningen om socialt kapital för att sända ett budskap till människor om att missförhållandena i deras samhällen orsakas av alltför lite frivillig verksamhet. ${ }^{5}$ Men tänk om förtroendets och det sociala kapitalets låga nivåer beror på att staten inte gör tillräckligt för att minska ojämlikheten?

\section{Om behovet av en icke-korrupt regering}

Vi placerar i vår argumentering ojämlikhet i början av orsakskedjan, men vi är också övertygade om att låg korruption betyder mycket för genomförandet av generella välfärdsprogram. Det finns kanske inget direkt samband mellan en effektiv regering och förtroende, men en korrupt regering undergräver förtroendet åtminstone indirekt, och gör det svårt att genomdriva generella välfärdsprogram (Uslaner 2005).

En icke-korrupt regering är viktig för genomförandet av generella välfärdsprogram av tre skäl. För det första bygger korruption på att man känner lojalitet mot innegruppen och inte mot det större samhället; generella välfärdsprogram är således anatema för ohederliga regeringar (Gambetta 1993). Korrupta samhällen speglar patron-klient-förhållanden, och korrupta ledare belönar bara dem som visar lojalitet mot dem och inte mot det större samhället.

För det andra kräver generella politiska åtgärder högre beskattningsnivåer än inkomstprövade program, och ohederliga regeringar kommer att ha mindre resurser att spendera. Korruption överför resurser från den stora allmänheten till eliter - och i allmänhet från de fattiga till de rika (Tanzi 1998). Korruption blir funktionellt sett en extra skattebörda för medborgarna, vilket lämnar mindre pengar över för offentliga utgifter (Mauro 1997, s. 7).

5. Putnam \& Feldstein 2003. Se även, t.ex., den statliga irländska utredningen The Policy Implications of Social Capital (National Economic and Social Forum 2003); och i Sverige SOU 2000:I. Om Australien, se Winter red. 2000. Världsbanken har också varit mycket aktiv på det här området, se Woolcock \& Narayan 2000. 
Korrupta regeringar har mindre pengar att spendera på sina egna projekt och håller nere lönerna för de offentliganställda. Dessa kommer i sin tur att bli mer benägna att pressa fram mer pengar ur statskassan. De offentliganställda i korrupta samhällen kommer alltså att lägga ner mer tid på att fylla sina egna fickor än att tjäna allmänheten. När politiska ledare tänker på egen ekonomisk vinning blir det inte bara mindre resurser över för sociala program, utan allmänheten kommer att känna mindre förtroende för regeringen - folk kommer bara att betala höga skatter om de tror att de får något tillbaka i form av tjänster och bidrag (Hanousek \& Palda 2004).

För det tredje gynnar generella välfärdsprogram visserligen framväxten av ett generaliserat förtroende, men de kommer sannolikt inte att anammas i samhällen där jämlikheten och förtroendet redan är föga utvecklade.

Korruption har en indirekt effekt på förtroendet i den statistiska analysen i tabell I. Korruption leder till större ojämlikhet, vilket i sin tur skapar lägre nivåer av förtroende. Medan Uslaner (2004; 2005) i sin analys visar på en koppling mellan låga nivåer av förtroende och höga nivåer av korruption, men inte mellan korruption och förtroende, visar data från Rumänien och Estland att föreställningar om utbredd korruption gör människor mindre benägna att lita på sina medmänniskor (data för Rumänien, se Uslaner \& Badescu 2004; för Estland, se Uslaner 2008). Experimentella undersökningar visar också att både (mer förtroendefulla) svenska och (mindre förtroendefulla) rumänska studenter - när de ställs inför scenariot att statliga tjänstemän i en "okänd stad i ett okänt land" begär och även får mutor - förlorar förtroendet inte bara för dessa tjänstemän (poliser och läkare) utan även för "människor i allmänhet" i denna "okända stad". ${ }^{6}$

Stoyanov med flera rapporterar från en undersökning i Bulgarien att "skälen till att människor är rika ... hänger främst ihop med att det orättvisa sociala systemet garanterar bättre möjligheter för dem som saknar skrupler och har goda förbindelser ... den negativa föreställningen

6. Eek \& Rothstein 2005. Detta paper innehåller bara data om svenska studenter, men data från våra scenarioexperiment med rumänska studenter har sedan dess analyserats och bekräftar resultaten från experimenten i Sverige. 
om rika människor representerar inte bara den kommunistiska socialisationsstereotypen utan är också ett resultat av senare ... erfarenheter av korruption, organiserad brottslighet och 'illegal' rikedom" (Stoyanov m.fl. 2000, s. 35). 80 procent av personerna i undersökningar gjorda i Bulgarien, Ungern och Ryssland säger att höga inkomster speglar ohederlighet (Kluegel \& Mason 2000, s. I67; jfr Örkény 2000, s. I09.), medan man i Västeuropa är mer benägen att tro att framgång har med enskilda initiativ att göra (Csepeli m.fl. 2004). Örkény och Székelyi presenterar data som visar att människor i transitionsländer är långt mer benägna än medborgare i västeuropeiska länder att tro att människor har lika stora möjligheter att lyckas, blir belönade för sina ansträngningar och får vad de förtjänar; det är i stället, enligt deras mening, huvudsakligen förbindelser och ohederlighet som ligger bakom människors rikedom (Örkény \& Székelyi 2000, s. 206, 208).

När människor tror att enda vägen till välstånd går genom ohederlighet ökar de sociala spänningarna (Csepeli m.fl. 2004). Detta skapar en situation där vanliga medborgare tar avstånd från generella välfärdsprogram och i stället kräver omfördelning av inkomster. I Rumänien ledde föreställningar om existensen av en allmänt utbredd korruption, personliga erfarenheter av korruption och upplevelser av växande ojämlikhet till krav på begränsning av de rikas inkomster (Uslaner \& Badescu 2004). Där den sociala solidariteten är dåligt utvecklad på grund av klassavund kommer de sociala banden av generaliserat förtroende och villigheten att betala skatt (främst hos medelklassen) att vara svaga. Människor kommer att identifiera sig mer med sin klass eller etniska grupp än med samhället i stort. Och de kommer inte att lita på att regeringen fördelar resurser på ett rättvist och icke-korrupt sätt. Rohter sammanfattar detta dilemma i Latinamerika:

Jag tror inte att det finns någon viktigare fråga i Latinamerika just nu ... Det är en ond cirkel som är svår att bryta. Människor vill inte betala skatt eftersom de säger att staten inte tillhandahåller några tjänster, men de statliga institutionerna tänker inte fungera bättre förrän de har resurser, som de erhåller när människor betalar sina skatter (Rohter I999, s. 3). 
I samhällen med lågt förtroende och stor ekonomisk ojämlikhet kommer generella program sannolikt att misslyckas i brist på politiskt stöd. Även när man försöker införa sådana program är sannolikheten stor för att de misslyckas i implementeringsprocessen. Utbildning, sjukvård och sjukförsäkringsförmåner (liksom polisiära och rättsliga tjänster) kan mycket väl bli varor till salu eftersom korruptionen är så omfattande. Föräldrar "köper" platser i bra skolor, särskilt universitet, för sina barn och betalar ännu mer för goda betyg. Extra "gåvoersättningar" till läkare är rutin i länder med stor ekonomisk ojämlikhet. Poliser stoppar bilförare för påhittade trafiköverträdelser och fotgängare för att de har försökt korsa gatan mitt i trafikströmmen och kräver pengar i stället för att ge dem bötesföreläggande. Alla dessa handlingar undergräver förtroendet för staten och därmed föreställningen att den kan genomföra en generell socialpolitik på ett rättvist och jämlikt sätt. I stället misstänker man allmänt att byråkrater kommer att ge extra förmåner till dem som vill och kan ge "extra" betalning (Kornai 2000).

I länder med omfattande korruption är människor i gemen fientligt inställda till dem som har mer. De tror att de fattiga behandlas orättvist av samhället i stort och framför allt av statliga institutioner. Låginkomstgrupper röstar därför sannolikt för vänsterpartier som förordar en mer "radikal" omfördelning av resurser än vad som skulle ske genom generella välfärdsprogram (Di Tella \& MacCulloch 2003). I en sådan situation är det lätt för "radikala" politiska entreprenörer att hävda att man genom att bestraffa dem som skaffar sig rikedom på olagligt sätt (till exempel genom olika former av korruption) skapar social rättvisa. Ojämlikhet och korruption skapar alltså misstro och inte stöd för just den typ av välfärdsprogram som effektivast minskar ojämlikheter i inkomster.

\section{Institutioner för jämlikhet och socialt förtroende: Hur började det?}

Olika länder opererar i olika kausala cykler mellan sina socialpolitiska institutioner och sin nivå av socialt förtroende. Detta väcker svåra frågor om hur denna kausala logik började. Utvecklade de skandinaviska länderna en generell socialpolitik därför att det redan existerade ett starkt 
socialt förtroende och mindre social ojämlikhet, eller var det tvärtom? Eftersom vi inte har några data om graden av socialt förtroende från I920-talet är detta svårt att svara på. Men det har gjorts några historiska studier om karaktären hos de samhällen som existerade i Skandinavien innan den generella typen av socialpolitik infördes.

I tidigmodern tid hade de skandinaviska länderna en mer jämlik social struktur än resten av Europa (Flora red. 1986; jfr Tilly 1992). De svenska och norska bönderna var inte underkastade någon feodalism av kontinental typ utan var rättsligt självständiga. Fram till representationsreformen 1867 utgjorde bönderna i Sverige ett eget stånd, en situation som var unik i Europa. Enligt Charles Tilly var det "två förhållanden ... som starkt påverkade den svenska statens formering. För det första den överväldigande närvaron av en bondeklass som ägde stora jordegendomar långt in på I700-talet, och för det andra adelns oförmåga att bilda stora gods eller tvinga bönderna att arbeta på sina marker” (Tilly I992, s. 27). Detta gällde också för Norge, som till och med saknade adel. I Danmark hade bönderna och städernas borgerskap störtat absolutismen I849. Böndernas politiska styrka växte gradvis under decenniernas gång. De konsoliderade sig som en självständig och mäktig politisk klass genom att bilda producentorganisationer, försäkringsbolag, sparbanker, kulturella och pedagogiska institutioner med mera. Detta gjorde de i mycket större skala än i andra länder. Politiskt förenade bönderna sig i slutet av I80o-talet i det liberala partiet venstre, som kom till makten I90I (Knudsen I995).

För det andra hade det växt fram en regelstyrd, huvudsakligen meritokratisk och tämligen okorrumperad statsförvaltning i de skandinaviska länderna (Knudsen \& Rothstein 1994; Knudsen \& Tamm red. 2000). När de sociala reformer som blev inledningen till den sociala politikens generella principer infördes var det knappast någon som misstänkte att den förvaltning som skulle ha hand om programmen var korrupt. Reformerna var starkt omstridda, men det argumenterades aldrig för att förvaltningen var korrupt och att man därför inte kunde lita på den - eller har åtminstone aldrig rapporterats i de historiska studierna av den svenska välfärdsstatens första stadier (jfr Hort 20I4). Det har inte saknats klasskonflikter i Skandinavien. De var synnerligen bittra i mitten av I930-talet, 
och särskilt Sverige förlorade många arbetsdagar per arbetare på grund av strejker redan på 1920-talet (Elvander 1979). Men konflikterna löstes till slut fredligt, uppenbarligen på grund av landets långa historia av större jämlikhet än i övriga Europa och ett förtroende för de styrande som utvecklats under en lång tradition av icke-korrupt regeringsstyre.

En detaljerad genomgång av den historiska utvecklingen i det svenska fallet visar att det var ovälden hos de statliga institutionerna, särskilt de som hanterade arbetsmarknadsfrågor och socialpolitiska åtgärder, som gjorde utvecklingen av en "historisk kompromiss" mellan arbete och kapital möjlig. Denna kompromiss byggde i stor utsträckning på "en anda av förtroende"7 som utvecklades till den välkända "svenska modell" som kom att prägla det svenska samhället efter 1936 (Rothstein 2005; jfr Katzenstein 1985).

Det är mycket som tyder på att det var existensen av opartiska, okorrumperade och tämligen effektiva statliga institutioner som lade grunden för de uppgörelser mellan eliter som bidrog till att skapa starka normer om förtroende i Sverige. Det var ett allmänt förtroende för ledares och institutioners integritet som låg bakom de kompromisser om generella socialpolitiska åtgärder som skulle minska ojämlikheten och öka den sociala sammanhållningen och tilliten. De skandinaviska länderna var historiskt mindre ojämlika än länderna på kontinenten, och hade dessutom lägre nivåer av korruption i sina statliga institutioner.

\section{Social politik och socialt förtroende}

Vill man minska ojämlikheten är det bättre att driva generell välfärdspolitik än att genomföra enkla selektiva omfördelningsprojekt (Rothstein I994; Korpi \& Palme 1998). Detta är en paradox eftersom man skulle tro att en generell politik som ger alla samma service eller bidrag, till exempel allmänt barnbidrag eller allmän sjukvård, inte skulle ha några

7. Så beskrev den tidens aktörer, både från fackföreningsrörelsen och arbetsgivarna, vad som hände i mitten av 1930-talet; se Rothstein 2005, kap. 7. Särskilt viktigt var att den socialdemokratiska partiledningen kunde göra "trovärdiga utfästelser" till SAF att den inte skulle utnyttja sin politiska makt över statsförvaltningen för att gynna den fackliga sidan, till exempel i arbetsmarknadskonflikter. 
omfördelande verkningar, medan en omfördelningspolitik som beskattar de rika och ger till de fattiga skulle vara det effektivaste sättet att minska fattigdomen. Men det förhåller sig faktiskt tvärtom (Swank 2002). Det "tekniska" skälet till att generella system är effektivare när det gäller att minska den ekonomiska ojämlikheten är att skatter vanligen är proportionella eller progressiva medan service eller bidrag är nominella - man får en viss summa eller en viss typ av tjänst (Åberg 1989; Moene \& Wallerstein 200I).

Nettoeffekten av proportionella (eller progressiva) skatter och nominella tjänster/bidrag är en betydande omfördelning från de rika till de fattiga. Det politiska skälet till att generella politiska åtgärder är effektivare är att om en stat beskattar de rika och ger till de fattiga, kommer de rika (särskilt medelklassen) inte att vilja betala de högre skatterna eftersom de inte uppfattar att de får något tillbaka (Korpi \& Palme I998; Swank 2002). De kommer att betrakta sådana program som enbart avsedda för "de fattiga", och framför allt medelklassen (som också är marginalväljare) kommer att fly från partier som argumenterar för ökade skatter och socialpolitiska åtgärder (Rothstein 1994; Swank 2002).

Till detta kommer att man i genomförandet av generella program följer två viktiga jämlikhetsprinciper. För det första behandlar dessa program alla i samma situation lika. För det andra krävs det med generella program ingen stor byråkrati för att fastställa enskilda människors behov. Selektiva välfärdsprogram stigmatiserar ofta mottagarna som "välfärdsklienter". De stakar ut gränser mellan rika och de fattiga, där de senare kommer att känna sig mindre värda, inte minst på grund av det byråkratiska intrång som är förbundet med implementeringsprocessen (Kumlin \& Rothstein 2005). Generella program är förbundna med medborgerliga rättigheter, medan selektiva välfärdsprogram har problem med legitimiteten eftersom de måste skilja ut de "värdiga" från de "ovärdiga" fattiga. Detta kommer alltid att kräva beslut från byråkrater som kan inkräkta på klientens personliga integritet.

Människor som mottar selektiva sociala bidrag känner sig ofta förnedrade och isolerade från andra i samhället. De är mer benägna att anse att staten är avlägsen och onåbar, och att det inte skulle leda någonting till att delta i den politiska processen. Däremot skiljer sig de som mottar 
icke inkomstprövade bidrag inte från befolkningen i allmänhet i dessa avseenden.

Förklenande tal om inkomstprövade välfärdsprogram leder till sociala spänningar på två sätt: De fattiga känner sig isolerade och tycker att andra betraktar dem som ovärdiga, medan gemene man menar att de fattiga själva är ansvariga för sin fattigdom. Generella program "stämplar" däremot inte någon bidragsmottagare och undergräver alltså inte förtroendet. När de fungerar väl kan de till och med bidra till att skapa förtroende genom att förstärka känslan av att man får lika behandling och har lika stora möjligheter som alla andra.

I 1992 års American National Election Study (ANES) frågade man människor om de mottog inkomstprövade bidrag som socialbidrag och Medicaid (medicinsk hjälp riktad till fattiga människor). De som bara mottog sådana inkomstprövade bidrag, och inte generella ersättningar som Social Security eller Medicare (båda relaterade till ålder utan hänsyn till inkomst), var mindre benägna att lita på andra människor än de som inte mottog sådana bidrag: 2I procent av dem som mottog inkomstprövade bidrag litade på andra jämfört med 49 procent som inte mottog sådana bidrag.

När människor inte ser sig själva som en del av samma moraliska gemenskap kommer de att sakna den känsla av solidaritet som är väsentlig för byggandet av socialt förtroende. Inkomstprövningen stigmatiserar de fattiga och får dem att i viktiga avseenden känna sig "skilda" från andra i samhället och uppleva det som att staten bryr sig mer om välfärden för dem med större resurser. De amerikanska beläggen visar således att en välfärdsstat byggd huvudsakligen på inkomstprövade program inte så mycket ökar jämlikheten som vidmakthåller känslor av ojämlikhet både bland de fattiga och bland de mer förmögna. Detta gäller även när man tar hänsyn till faktorer som utbildning, etnicitet, ålder, ekonomisk ställning och socialpsykologiska grunder för förtroende.

Om vi jämför dessa amerikanska data med svenska data blir likheterna slående. Svenskar som är föremål för selektiva åtgärder, till exempel socialhjälp och förtidspension, känner betydligt lägre förtroende för andra personer än resten av befolkningen (Rothstein \& Stolle 2003). I en undersökning av svenska medborgares kontakter med olika välfärds- 
program uppmanades undersökningspersonerna att ange om de hade haft att göra med ett antal utvalda välfärdsinstitutioner. Den minoritet svenskar som hade varit i kontakt med selektiva program hade signifikant lägre socialt förtroende än resten av befolkningen. Den negativa effekt på det sociala förtroendet som interaktionen med behovsprövande institutioner hade förblev statistiskt signifikant när man kontrollerade för andra variabler som man vet påverkar det sociala förtroendet (utbildningsnivå, samhällsklass, inkomst, aktivitet i frivilligorganisationer, intresse för politik, allmänt välbefinnande, politisk ideologi och sysselsättning). Svenska data visar att kontakterna med behovsprövande välfärdsinstitutioner tycks minska förtroendet mellan människor även när ett stort antal andra faktorer tas med i beräkningen (Kumlin \& Rothstein 2005) - precis som vi noterade för USA.

\section{Generella program och socialt förtroende}

En del av svaret på frågan om varför länder med stora och huvudsakligen generella välfärdsprogram har mer socialt förtroende är att dessa program skapar samhällen med mindre ekonomisk ojämlikhet. Men fördelarna kan vara mer substantiella än så. För det första kräver generella program inte så mycket byråkratisk kontroll. För det andra kan generella program skapa en känsla av social sammanhållning i samhället. Patienter, äldre människor, förskolebarn och skolelever separeras inte i olika tjänstesfärer beroende på om de betecknas som "fattiga" eller ej. Dessa program stöds av de fattiga, men också av medelklassen och av högutbildade samhällsskikt (Svallfors 1997). Även under perioder då mitten- och högerpartier har haft makten i Skandinavien (som de framför allt har haft i Danmark och Norge) har välfärdsstatens generella karaktär bestått (Swank 2002; Huber \& Stephens 200I). Preferenserna för "ekonomisk utjämning" - för en rättvisare inkomstfördelning - är mycket starkare i de skandinaviska länderna än bland andra utvecklade industriländer, och de är svagast i USA och Storbritannien, som båda har en lång historia av inkomstprövade bidrag (Osberg \& Smeeding 2005).

För det tredje kan existensen av högkvalitativa generella program, särskilt när det handlar om områden som utbildning och sjukvård, öka 
känslan av "optimism" och av att ha "lika möjligheter" bland stora delar av befolkningen. De nordiska länderna spenderar jämförelsevis mycket på sociala tjänster och utbildning. Till och med universitetsutbildning finansieras genom skatter: staten erbjuder relativt generösa studiebidrag och studielån, och det förekommer inga studieavgifter. Data från en rad länder, till exempel Sverige, USA och Rumänien, visar att höga utbildningsnivåer leder till höga nivåer av generaliserat förtroende (Brehm \& Rahn 1997; Knack \& Zak 2003; Putnam 1995; Uslaner 2002, kap. 4; Uslaner 2003).

I enlighet med den betoning av det enskilda initiativet som präglar den amerikanska politiska kulturen har USA halkat efter de europeiska länderna när det gäller att erbjuda generella bidrag (Alesina \& Glaeser 2004). De stora undantagen är Social Security och Medicare, pension respektive medicinsk försäkring för äldre. Men även om Medicare är ett generellt system utan inkomstprövning varierar kvaliteten på tjänsterna till patienterna mellan olika delstater. Förvaltningen av systemet formas av de sociala krafterna i respektive delstat. Där ojämlikheten är hög är förtroendet lågt; den sociala solidariteten räcker inte till för att ge högkvalitativ vård till alla medborgare.

Här ser vi belägg för den ojämlikhetsfälla vi nämde ovan: när ojämlikheten har ökat i USA har trycket på att göra mer för de fattiga minskat och utgifterna för program avsedda för de mest behövande skurits ner. Ojämlikhet framkallar lägre nivåer av förtroende. I960 ansåg 58 procent av USA:s befolkning att "man kan lita på de flesta människor", men sedan I990-talet har detta tal sjunkit till mellan 33 och 40 procent. Denna sjunkande nivå av förtroende framkallar ökande polarisering och konkurrens om statliga resurser - och mindre stöd för program som gynnar de mest behövande. De högre nivåerna av jämlikhet och förtroende i de skandinaviska länderna har däremot upprätthållit välfärdsstaten. Ojämlika samhällen är fångade i en social fälla av hög ojämlikhet och lågt förtroende, där förtroendenivån är för låg för att kunna ligga till grund för den generella välfärdspolitik som skulle minska ojämlikheten. 


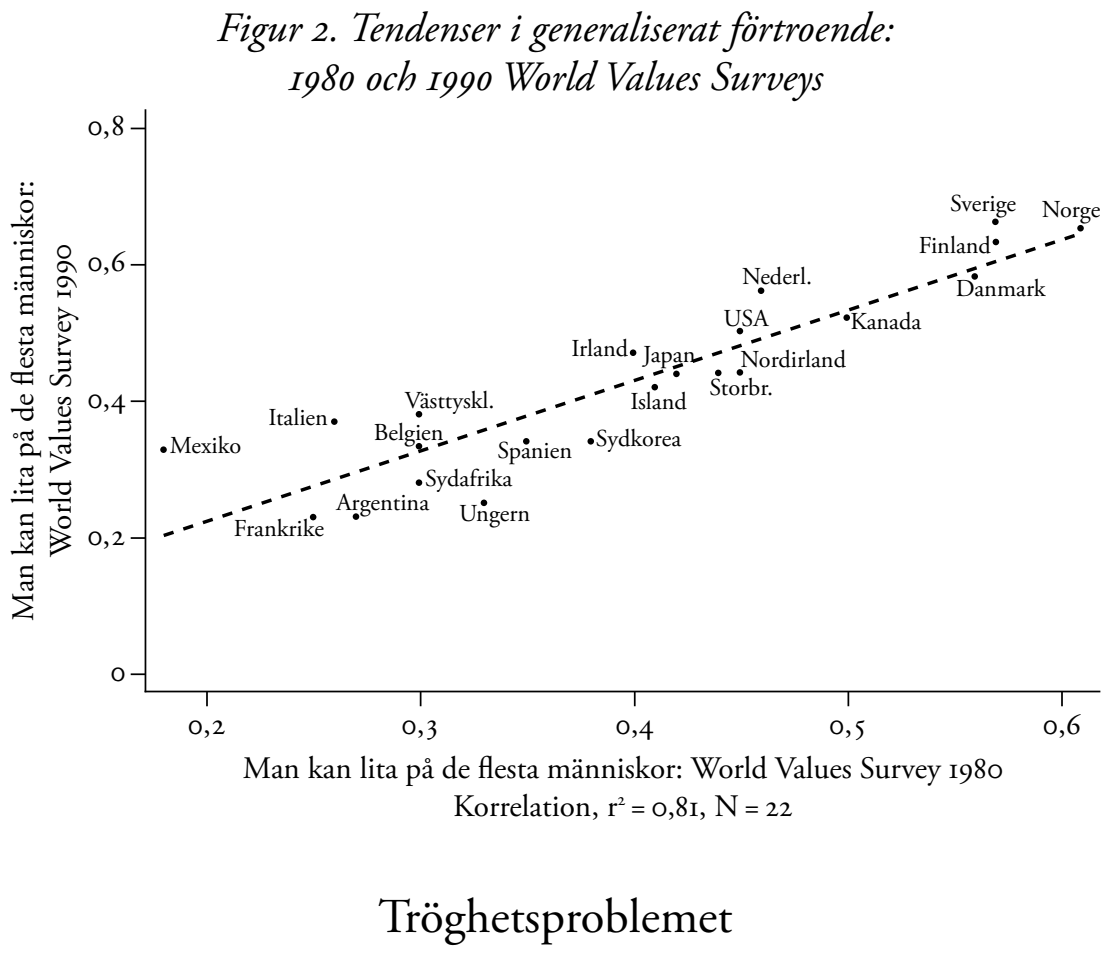

Förtroende, ojämlikhet och korruption är alla tröga fenomen: inget av dem förändras särskilt mycket över tiden. Korrelationen mellan generaliserat förtroende i World Values Survey 1980 och generaliserat förtroende I990 är 0,8I för de 22 nationer som ingår i båda vågorna (se figur 2) korrelationen mellan generaliserat förtroende 1990 och generaliserat förtroende 1995 är också robust $(0,85 \mathrm{I}, \mathrm{N}=28)$. Inte heller ojämlikheten har förändrats särskilt mycket. Korrelationen för det oftast använda måttet på ekonomisk ojämlikhet (Deininger \& Squire 1996) mellan ı980 och I990 är inte lika hög som för förtroendet, men är ändå så hög som 0,676 för ett urval på 42 länder (se figur 3). En ny databas för ojämlikhet som utvecklats av James Galbraith utvidgar måtten på ojämlikhet ännu längre tillbaka i tiden och till ännu fler länder. ${ }^{8}$ Korrelationen mellan ekonomisk ojämlikhet 1963 och ekonomisk ojämlikhet 1996 är 0,706 (N = 37;

8. Data kan erhållas från http://utip.gov.utexas.edu/. 
ARKIV 1 NR 4

\section{Figur 3. Tendenser i ojämlikhet: Gini-koefficient 1990 och I980}
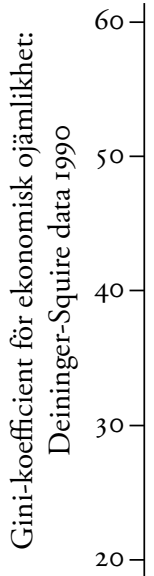

ndien

Pakistan. Irland Portugal

Italien:

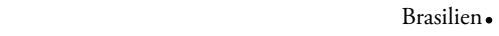

Finland Kanada - - Syerige• Kina

-Colombia

Chile

Peru •.̈̈sttyskl.

Filippinerna.
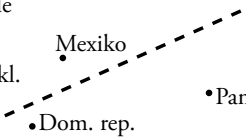

- Panama

-Argentina •Venezuela

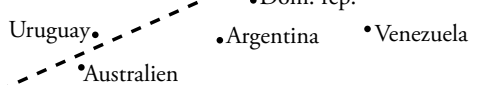

Västtyskland ${ }^{\circ}$ - Ó Ósterrike Danmark

Bulgarien Spanien Nederl. Storbr

Tjeckien. Polen $\begin{gathered}\text { Ryssland } \\ \text { Serbien.• Ungern }\end{gathered}$

30

40

50

Gini-koefficient för ekonomisk ojämlikhet: Deininger-Squire data I980

Korrelation, $\mathrm{r}^{2}=0,676, \mathrm{~N}=42$

Figur 4. Tendenser i ojämlikhet: Gini-koefficient 1996 och 1963

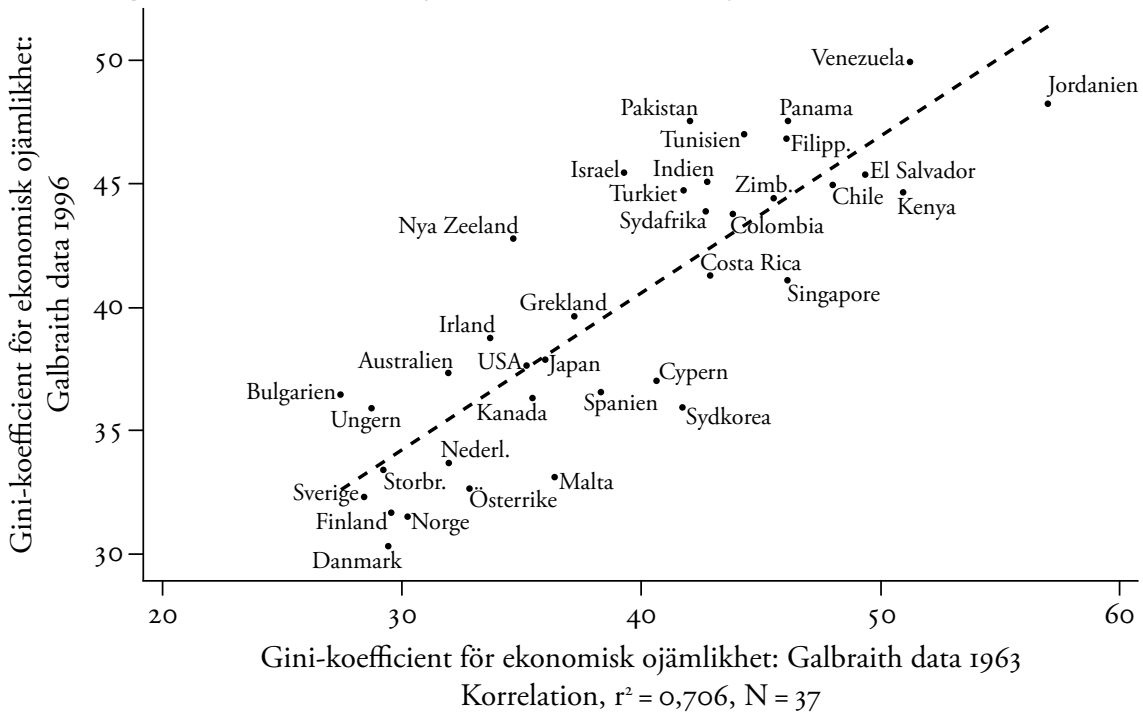




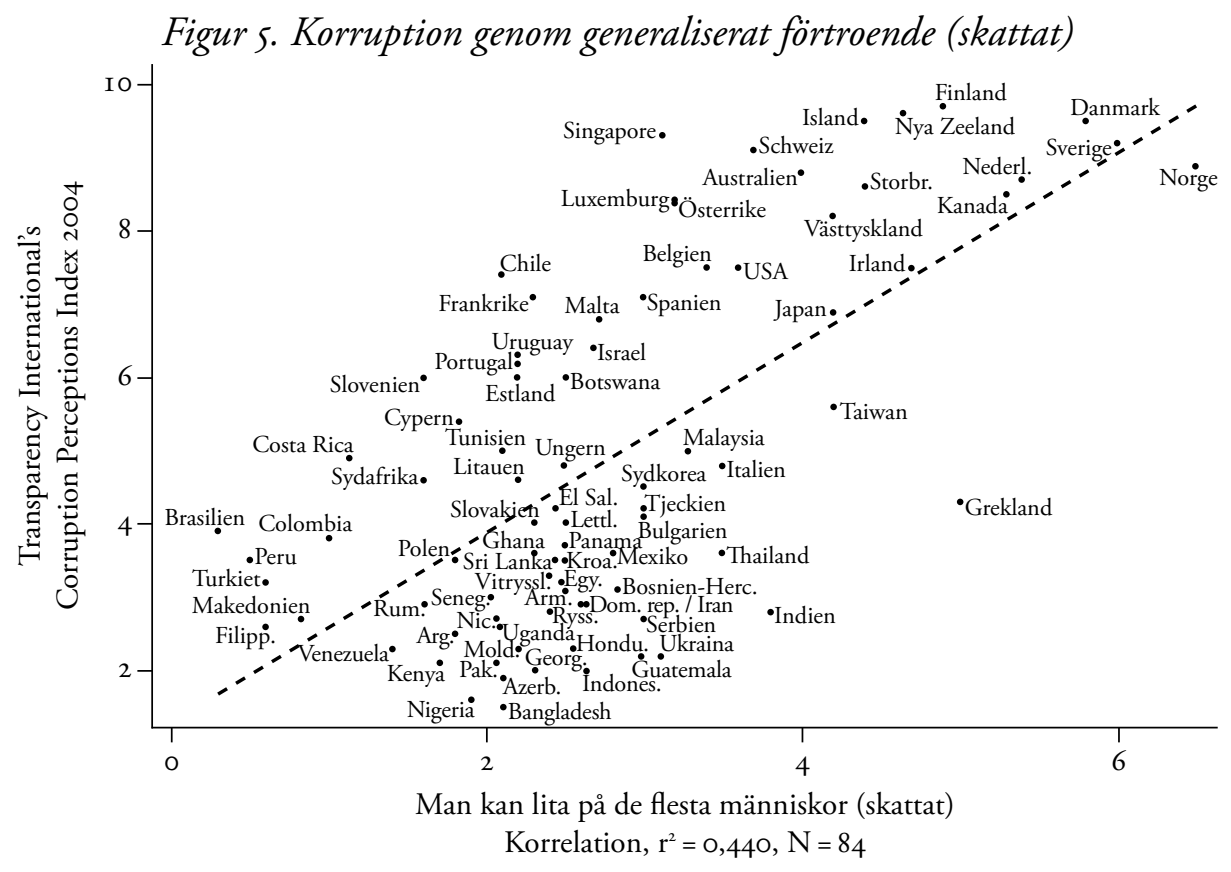

se figur 4). Ojämlikhet består över tiden - den är förhållandevis orörlig. Denna bestående karaktär leder till lägre nivåer av förtroende och en ovilja att acceptera politiska åtgärder som kan minska ojämlikheten.

Vi ser en liknande dynamik för korruption. Korrelationen mellan 2004 års Transparency Internationals skattningar av korruption och International Country Risk Guides skattningar för 1980-85 gällande 52 länder är 0,742 . Och korrelationen mellan förtroende och korruption 2004 för 84 länder är o,440 (se figur 5). Förtroende, ojämlikhet och korruption är alla trögrörliga - och de tycks bilda ett gemensamt syndrom.

Det verkar således finnas flera jämviktspunkter. I den "goda cykeln" har några länder låg ojämlikhet, högt förtroende, låg korruption och en generell välfärdspolitik. Dessa länder började med en jämnare spelplan och har den sociala struktur, de välfungerande institutioner och den politik som håller ojämlikheten i schack. I den "onda cykeln” tycks länderna 
sitta fast i hög (eller växande) ojämlikhet, lågt förtroende, hög korruption och krav på en mer radikal omfördelning - en politik som bara kommer att öka de sociala spänningarna ytterligare och inte kommer att uppnå målet att minska den ekonomiska ojämlikheten. När ojämlikheten är mycket låg (de tjugosju fall där Gini-koefficienten är 0,35 eller lägre) är korrelationen mellan ojämlikhet och förtroende ytterst liten (o,or3); vi ser samma fenomen när ojämlikheten är hög (större än 0,42 ): korrelationen är bara $0,013(\mathrm{~N}=23)$. Inte heller $\mathrm{i}$ intervallet där emellan förekommer så mycket rörelse (korrelationen =0,05I, $\mathrm{N}=\mathrm{I} 4$ ). Detta är kärnan i ojämlikhetsfällan: det är inte lätt att göra Brasilien till ett Sverige eller Finland. Faktiskt är det inte heller lätt att göra Brasilien till ett Portugal, eller ett USA till ett Sverige eller ens Kanada.

\section{Universalismens, förtroendets och jämlikhetens sociala fälla}

Upplevelsen av ojämlikhet får den fattige att kräva omfördelning och den rike att förkasta detta krav. Vi ser denna ojämlikhetsfälla mycket tydligt i Centraleuropa och Östeuropa, där länderna gått över från kommunism till demokrati, även om historien är ungefär densamma i andra utvecklingsländer med höga nivåer av fattigdom och ojämlikhet och låga nivåer av förtroende.

Framväxten av en marknadsekonomi har inneburit att många tidigare statligt anställda har förlorat sin garanterade sysselsättning och inte längre har en lön som kan leva på. Kommunismen hade redan sänkt nivån för generaliserat förtroende. Att övervinna både fattigdomen och den låga förtroendenivån stod högt upp på den politiska dagordningen i dessa länder efter kommunismens fall, men det har inte funnits något större stöd för den Däremot tycks det finnas stöd för en mer radikal omfördelning av inkomsterna som ju bara skulle förvärra spänningarna och göra övergången svårare.

Varje övergångsland för vilket det finns data om förändringar i ekonomisk ojämlikhet (utom Slovakien) visade en ökning av den ekonomiska ojämlikheten från 1989 till mitten av 1990-talet (Rosser, Rosser \& Ahmed 2000). När ojämlikheten växer ser vi en klar koppling mellan 
förnimmelsen av växande ojämlikhet och övertygelsen att enda sättet att bli rik är genom korruption.

Att vinna framgång i livet får betydelse av två skäl. För det första är det generaliserade förtroendet starkt beroende av optimism och kontroll - en tro att livet är bra och kommer att bli bättre, och att man själv kan bidra till att det blir bättre. Det andra skälet är att när människor är rädda för framtiden och ser ojämlikheten växa, blir de mindre benägna att vara optimistiska (Uslaner 2002, kap. 4-8). Tror man att man behöver speciella förbindelser eller tur för att vinna framgång, ser man sig inte längre som i kontroll över sitt eget liv. En sådan pessimism om möjligheten att påverka sin framtid leder till lägre nivåer av generaliserat förtroende i länder så olika som USA och Rumänien (Uslaner 2002, kap. 4, 6; jfr Rose-Ackerman 2004). I samhällen som befinner sig i en övergångsfas är förtroendet redan lågt. När ojämlikheten växer ställs det krav på omfördelning av rikedomen och konfiskering av de nyrikas förmögenheter.

Den bästa politiska reaktionen på växande ojämlikhet är att genomföra generella välfärdsprogram, men de sociala spänningar som blir resultatet av den ökade ojämlikheten gör det nästan omöjligt att genomföra en sådan politik. Krav på omfördelning kommer alltså att leda till ineffektiva strategier för minskning av fattigdomen och till ännu större sociala spänningar. Övergångsstaterna, där jämlikheten i utgångsläget var relativt stor, hade en gyllene möjlighet att driva igenom en generell välfärdspolitik. Men de hade också korrupta regeringar, skatteflykten var omfattande och det allmänna förtroendet var lågt. De hade bara ett av de centrala element, relativ jämlikhet, som krävdes för genomförandet av en generell välfärdspolitik. I avsaknad av det andra elementet, hederligt regeringsstyre, har de inte kunnat hejda den växande ojämlikheten och de sociala spänningar som är förbundna med den. Många övergångsstater förde faktiskt en generell välfärdspolitik under den kommunistiska regimen, och de flesta av dem bekänner sig fortfarande officiellt till en sådan, men när man försöker genomföra den fokuserar man mer på riktade bidrag och sjukvården bygger i allmänhet på människors förmåga att betala sin egen försäkring (EU-kommissionen 2003). De flesta övergångsländer har alternerat mellan högerregeringar och vänsterregeringar 
i sökandet efter ekonomisk stabilitet. En sådan politisk instabilitet, med svängningar från den ena polen till den andra, speglar bristen på socialt samförstånd.

\section{Slutsatser}

Om, som vi hävdar, socialt förtroende skapas av två typer av jämlikhet, och om generella politiska åtgärder är det bästa sättet att öka dessa typer av jämlikhet kan många länder med låga nivåer av socialt förtroende och socialt kapital ha fastnat i ett slags social fälla (Rothstein 2005). Logiken i en sådan social situation är följande: Det sociala förtroendet kommer inte att öka eftersom det råder en omfattande social ojämlikhet, men den politik som skulle kunna råda bot på situationen kan inte drivas just för att det råder brist på förtroende. Bristen på förtroende gäller både "andra människor" och de statliga institutioner som krävs för att genomföra en sådan politik. Eftersom socialt förtroende är ett viktigt värde i sig (personlig lycka, optimism om framtiden) och även har politiskt värde (stöd för rättvisa institutioner, minoritetsinstitutioner, tolerans och så vidare) och ekonomiskt värde (positiv relation till individuella inkomster och samlad ekonomisk tillväxt) kan dysfunktionella statliga institutioner vara det allvarligaste sociala missförhållandet.

Fattiga och ojämlika länder befinner sig alltså fängade i en situation av bestående ojämlikhet, misstro och dysfunktionella institutioner. Höga nivåer av ojämlikhet bidrar till lägre nivåer av förtroende, vilket minskar det politiska stöd som staten behöver för att kunna inrätta och genomföra generella välfärdsprogram på ett okorrumperat och icke diskriminerande sätt. Som vi har sett i många övergångsländer förvärrar kraven på radikal omfördelning de sociala spänningarna snarare än att lätta dem.

Det kommer inte att finnas något politiskt stöd för generella program eftersom de rika har fördel av korruptionen och betraktar de fattiga som "ovärdiga fattiga". De fattiga ser nästan all framgång i marknadsekonomin som belägg för ohederligt beteende och anser att de välbärgade redan har fătt mer än nog från staten. Ur det perspektivet blir idén att även de rika ska ha tillgång till statliga välfärdstjänster och bidrag svårsmält. Och även om man kan frambringa tillräckligt politiskt stöd 
för införandet av generella välfärdsprogram litar man kanske inte på att de statliga institutionerna förvaltar dem rättvist och okorrumperat. Med den ständiga förekomsten av korruption kan det verka rationellt att ge "gåvoersättningar". Det kan kännas tryggare att veta att man kan köpa en bra skola och goda betyg till sina barn än att riskera bedömningar efter mer neutrala kriterier. Man kan föredra att göra en extra betalning hos doktorn i stället för att vänta på sin tur. Korruption föder ekonomisk ojämlikhet, lågt förtroende och ineffektivitet hos statliga institutioner och stimulerar alternativa sätt att agera som gör det svårt att införa program som kan minska ojämlikheten.

Vårt budskap är onekligen pessimistiskt. Men vi tycker att det finns anledning till det med tanke på hur trögrörliga både ojämlikheten och den låga graden av förtroende är. Alltför många av de recept på politiska åtgärder som har lanserats har varit överdrivet optimistiska, till exempel tanken att om bara människor engagerar sig mer i frivilliga organisationer kommer situationen att förbättras. Vi menar att detta är fel av tre skäl. För det första finns det inga empiriska belägg för att det skapas generaliserat förtroende genom deltagande i frivilligorganisationer. För det andra befriar det staten från att ta ansvar för dysfunktionella institutioner och orättvisa eller ineffektiva politiska program. För det tredje kan staten och den politiska eliten utnyttja dessa krav på ökat deltagande i grupperingar i det civila samhället för att kasta skulden på offren själva.

Ojämlikhet är ett envist bestående fenomen, men den kan faktiskt rubbas. Generaliserat förtroende kan vara en väg till omfördelning, men det är inte den enda. Vi har därför anledning att dämpa vår pessimism en smula. De östasiatiska "tigrarna" uppnådde en dramatisk ekonomisk tillväxt och minskad ekonomisk ojämlikhet genom en rad politiska val som omfattade stora satsningar på utbildning, jordreformer, utbyggd sjukvård och friare marknader (Ahuja m.fl. 1997). Genom dessa politiska åtgärder blev olika statliga tjänster mer allmänt tillgängliga. Ekonomisk tillväxt och lägre befolkningstillväxt leder i sin tur till mindre ojämlikhet (Uslaner 2002).

Vi har inte de data som skulle göra det möjligt för oss att testa om ökad ekonomisk jämlikhet leder till större förtroende eller om ett land kan skapa större förtroende genom att inför en generell välfärdspolitik i 
frånvaron av antingen en relativ ekonomisk jämlikhet eller ett icke korrupt regeringsstyre. Vi är oroliga att den ökning av jämlikheten som krävs för att i betydande grad öka det generaliserade förtroendet kan vara större än vad vi har bevittnat under de senaste decennierna. Vi vet inte hur man ska göra sig kvitt korruption på institutionell väg. Men vi vet något om hur man ska minska ojämlikheten, nämligen genom generella socialpolitiska åtgärder. Men det är svårt att komma dithän, och vår prognos är som sagt föga optimistisk.

\section{Översättning: Sven-Erik Torhell}

\section{Referenser}

Ahuja, Vinod m.fl. (1997) Everyone's Miracle? Revisiting Poverty and Inequality in East Asia, Washington: World Bank.

Alesina, Alberto \& Edward L. Glaeser (2004) Fighting Poverty in the US and Europe. A World of Difference, New York: Oxford University Press.

Atkinson, Anthony B. (1999) "The Distribution of Income in the UK and OECD Countries in the Twentieth Century", Oxford Review of Economic Policy, I5, 4. Dor: http://dx.doi.org/I0.I093/oxrep/15.4.56

Beugelsdijk, Sjoerd, Henri L. F. de Groot \& Anton B. T. M. van Schaik (2004) ”Trust and Economic Growth: A Robustness Analysis", Oxford Economic Papers, ny följd, 56, I.

DoI: http://dx.doi.org/Io.Io93/oep/56.I.II8

Boix, Carles \& Daniel N. Posner (1998) "Social Capital: Explaining Its Origins and Effects on Government Performance", British Journal of Political Science, 28, 4.

Braithwaite, Valerie \& Margaret Levi (red.) (1998) Trust and Governance, New York: Russell Sage Foundation.

Brehm, John \& Wendy Rahn (1997) "Individual-Level Evidence for the Causes and Consequences of Social Capital", American Journal of Political Science, 4I, 3. URL: http://www.jstor.org/stable/2III684

Cook, Karen S. (red.) (200I) Trust in Society, New York: Russell Sage Foundation.

Cook, Karen S., Russell Hardin \& Margaret Levi (2005) Cooperation without Trust?, New York: Russell Sage Foundation.

Csepeli, György m.fl. (2004) "Blindness to Success: Social Psychological Objectives along the Way to a Market Economy in Eastern Europe”, i János Kornai, Bo Rothstein \& Susan Rose-Ackerman (red.), Creating Social Trust in Post-Socialist Transition, New York: Palgrave Macmillan.

Deininger, Klaus \& Lyn Squire (1996) "A New Data Set Measuring Income Inequality", World Bank Economic Review, Io, 3. URL: http://www.jstor.org/stable/3990058 
Delhey, Jan \& Kenneth Newton (2003) "Who Trusts? The Origins of Social Trust in Seven Societies", European Societies, 5, 2. DOI: http://dx.doi.org/IO.I080/I461669032000072256

Delhey, Jan \& Kenneth Newton (2004) Social Trust: Global Pattern or Nordic Exceptionalism?, Working Paper, Wissenschaftszentrum Berlin für Sozialforschung. URL: http://www.econstor.eu/bitstream/I0419/44134/I/394929810.pdf (9 oktober 20I5)

Di Tella, Rafael \& Robert MacCulloch (2003) Why Doesn't Capitalism Flow to Poor Countries?, manuskript, Harvard Business School.

URL: http://www.econ.yale.edu/ -shiller/behmacro/2003-II/macculloch-ditella.pdf (9 oktober 20I5)

Eek, Daniel \& Bo Rothstein (2005) Exploring a Causal Relationship between Vertical and Horizontal Trust, paper presenterat vid konferensen "Trust and Democracy: A Multidisciplinary Perspective", Göteborgs universitet, 19-20 maj 2005.

URL: http://www.pol.gu.se/digitalAssets/1350/1350645_2005_4_eek_rothstein.pdf (9 oktober 20I5)

Elvander, Nils (1979) Scandinavian Social Democracy. Its Strength and Weakness, Stockholm: Almqvist \& Wiksell International.

EU-kommissionen (2003) Social Protection in the I3 Candidate Countries: A Comparative Analysis, Luxemburg: European Commission Directorate-General for Employment and Social Affairs.

URL: http://www.eski.hu/new3/konyvtar/bookshop/Social\%2oprotection.pdf (9 oktober 2015)

Flora, Peter (red.) (1986) Growth to Limits. The Western European Welfare States since World War II, vol.I, Sweden, Norway, Finland, Denmark, Berlin: de Gruyter.

Gambetta, Diego (1993) The Sicilian Mafia. The Business of Private Protection, Cambridge: Harvard University Press.

Gottschalk, Peter \& Timothy M. Smeeding (1997) "Cross-national Comparisons of Earnings and Income Inequality", Journal of Economic Literature, 35, 2. URL: http://www.jstor.org/stable/2729789

Gustafsson, Björn \& Mats Johansson (1999) "In Search of Smoking Guns: What Makes Income Inequality Vary over Time in Different Countries?", American Sociological Review, 64, 4. URL: http://www.jstor.org/stable/2657258

Hacker, Jacob S. (2004) "Privatizing Risk without Privatizing the Welfare State: The Hidden Politics of Social Policy Retrenchment in the United States", American Political Science Review, 98, 2.

URL: http://www.jstor.org/stable/4I45310

Hanousek, Jan \& Filip Palda (2004) "Quality of Government Services and the Civic Duty to Pay Taxes in the Czech and Slovak Republics, and Other Transition Countries", Kyklos, 57, 2. DOI: http://dx.doi.org/I0.IIII/j.0023-5962.2004.00252.x

Hardin, Russell (2002) Trust and Trustworthiness, New York: Russell Sage Foundation. 
Helliwell, John F. (2002) How's Life? Combining Individual and National Variables to Explain Subjective Well-Being, Working Paper 9065, Cambridge: National Bureau for Economic Research. DoI: http://dx.doi.org/Io.3386/w9065

Hort, Sven E. O. [f.d. Olsson] (2014) Social Policy, Welfare State, and Civil Society in Sweden, vol. I, History, Policies, and Institutions I884-1988, 3 uppl., Lund: Arkiv förlag.

Huber, Evelyne \& John D. Stephens (200I) Development and Crisis of the Welfare State, Chicago: Chicago University Press.

Katz, Michael B. (1999) "In the Shadow of the Poorhouse: A Social History of Welfare in America", i Martin Gilens (red.), Why Americans Hate Welfare. Race, Media and the Politics of Antipoverty Policy, Chicago: University of Chicago Press.

Katzenstein, Peter J. (1985) Small States in World Markets. Industrial Policy in Europe, Ithaca: Cornell University Press.

Kinder, Donald R. \& Roderick Kiewiet (1979) "Economic Discontent and Political Behavior: The Role of Personal Grievances and Collective Economic Judgments in Congressional Voting", American Journal of Political Science, 23, 3.

Kluegel, James R. \& David S. Mason (200o) "Market Justice in Transition”, i David S. Mason \& James R. Kluegel (red.), Marketing Democracy, Lanham: Rowman and Littlefield.

Knack, Stephen \& Paul J. Zak (2003) "Building Trust: Public Policy, Interpersonal Trust, and Economic Development", Supreme Court Economic Review, Io. URL: http://www.jstor.org/stable/II47I39

Knudsen, Tim (1995) Dansk statsbygning, Köpenhamn: Jurist- og Økonomforbundets Forlag.

Knudsen, Tim \& Bo Rothstein (1994) "State Building in Scandinavia", Comparative Politics, 26, 2. URL: http://www.jstor.org/stable/422268

Knudsen, Tim \& Ditlev Tamm (red.) (2000) Dansk forvaltningshistorie indtil I9oI, Köpenhamn: Jurist- og Økonomforbundets Forlag.

Kornai, János (2000) Hidden in an Envelope: Gratitude Payments to Medical Doctors in Hungary, översatt paper, Collegium Budapest, Institute for Advanced Study. URL: http://www.colbud.hu/honesty-trust/kornai/pubor.PDF (9 oktober 20I5)

Korpi, Walter \& Joakim Palme (1998) "The Paradox of Redistribution and Strategies of Equality: Welfare State Institutions, Inequality, and Poverty in the Western Countries", American Sociological Review, 63, 5.

URL: http://www.jstor.org/stable/2657333

Korpi, Walter \& Joakim Palme (2003) "New Politics and Class Politics in the Context of Austerity and Globalization: Welfare State Regress in I8 Countries, 1975-95", American Political Science Review, 97, 3. DoI: http://dx.doi.org/Io.IOI7/Soo03055403000789

Kumlin, Staffan \& Bo Rothstein (2005) "Making and Breaking Social Capital: The Impact of Welfare-State Institutions", Comparative Political Studies, 38, 4. DOI: http://dx.doi.org/IO.II77/ooIO4I4004273203 
Mauro, Paolo (1997) Why Worry about Corruption?, paper i serien Economic Issues nr 6, Washington: International Monetary Fund.

URL: https://www.imf.org/EXTERNAL/PUBS/FT/ISSUES6/issue6.pdf (9 oktober 2015)

Moene, Karl Ove \& Michael Wallerstein (200I) "Targeting and Political Support for Welfare Spending", Economics of Governance, 2, I. DoI: http://dx.doi.org/Io.Ioo7/PLoooriors

National Economic and Social Forum (2003) The Policy Implications of Social Capital, Forum Report nr 28, National Economic and Social Forum, Dublin. URL: http://www.drugsandalcohol.ie/5696/I/NESF_No-28-Social-Capital.pdf (9 oktober 2015)

Neckerman, Katherine (2004) Social Inequality, New York: Russel Sage.

Osberg, Lars \& Timothy Smeeding (2005) Social Values for Equality and Preferences for State Intervention in the USA and Europe, manuskript, Center for Policy Research, Maxwell School, Syracuse University.

URL: http://myweb.dal.ca/osberg/classification/research/working\%2opapers/ Social\%20values\%2ofor\%2oequality/ToftvolumeOctoberıo2005.pdf (9 oktober 2015)

Ostrom, Elinor \& James Walker (red.) (2003) Trust and Reciprocity. Interdisciplinary Lessons from Experimental Research, New York: Russell Sage Foundation.

Pierson, Paul (2000) "Increasing Returns, Path Dependence, and the Study of Politics", American Political Science Review, 94, 2.

URL: http://www.jstor.org/stable/25860II

Putnam, Robert D. (1995) "Bowling Alone: America's Declining Social Capital”, Journal of Democracy, 6, I.

DOI: http://dx.doi.org/IO.I353/jod.1995.0002

Putnam, Robert D. (1996) Den fungerande demokratin. Medborgarandans rötter i Italien, Stockholm: SNS.

Putnam, Robert D. (2006) Den ensamme bowlaren. Den amerikanska medborgarandans upplösning och förnyelse, Stockholm: SNS.

Putnam, Robert D. \& Lewis D. Feldstein (2003) Better Together. Restoring the American Community, New York: Simon and Schuster.

Rohter, Larry (1999) "Where Taxes Aren't So Certain”, New York Times, 2I mars. URL: http:/www.nytimes.com/1999/03/2I/weekinreview/the-world-latin-america-scontagion-where-taxes-aren-t-so-certain.html (9 oktober 2015)

Rose-Ackerman, Susan (2004) "Public Participation in Consolidating Democracies: Hungary and Poland”, i János Kornai \& Susan Rose-Ackerman (red.), Building a Trustworthy State in Post-Socialist Transition, New York: Palgrave Macmillan.

Rosser, John Barkley, Jr., Marina V. Rosser \& Ehsan Ahmed (2000) "Income Inequality and the Informal Economy in Transition Economies", Journal of Comparative Economics, 28 , I.

DOI: http://dx.doi.org/IO.IOo6/jcec.2000.I645

Rothstein, Bo (1994) Vad bör staten göra? Om välfärdsstatens moraliska och politiska logik, Stockholm: SNS. 
Rothstein, Bo (2000) "Socialt kapital i den socialdemokratiska staten. Den svenska modellen och det civila samhället", Arkiv för studier i arbetarrörelsens historia, nr 79.

Rothstein, Bo (2005) Social Traps and the Problem of Trust, Cambridge: Cambridge University Press.

Rothstein, Bo \& Dietlind Stolle (2003) "Social Capital, Impartiality and the Welfare State: An Institutional Approach", i Marc Hooghe \& Dietlind Stolle (red.), Generating Social Capital. The Role of Voluntary Associations, Institutions and Government Policy, New York: Palgrave Macmillan.

Scocpol, Theda (2003) Diminished Democracy. From Membership to Management in American Civic Life, Norman: University of Oklahoma Press.

Seligman, Adam B. (1997) The Problem of Trust, Princeton: Princeton University Press.

SOU 2000:I. En uthållig demokrati! Politik för folkstyrelse på 2000-talet. Demokratiutredningens betänkande, Demokratiutredningen.

Stoyanov, Alexander m.fl. (200o) "Bulgaria: Political and Economic Crisis; Democratic Consolidation", i David S. Mason \& James R. Kluegel (red.), Marketing Democracy, Lanham: Rowman and Littlefield.

Svallfors, Stefan (1997) "Worlds of Welfare and Attitudes to Redistribution: A Comparison of Eight Western Nations", European Sociological Review, I3, 3.

Swank, Duane (2002) Global Capital, Political Institutions, and Policy Change in Developed Welfare States, New York: Cambridge University Press.

Tanzi, Vito (1998) "Corruption around the World: Causes, Consequences, Scope and Cures", IMF Staff Papers, 45, 4.

URL: https://www.imf.org/external/Pubs/FT/staffp/ı998/ı2-98/pdf/tanzi.pdf (9 oktober 2015)

Tilly, Charles (1992) Coercion, Capital, and European States, AD 990-1992, Oxford: Blackwell.

Tyler, Tom R. \& Yuen J. Huo (2002) Trust in the Law, New York: Russell Sage Foundation.

Uslaner, Eric M. (2002) The Moral Foundations of Trust, New York: Cambridge University Press.

Uslaner, Eric M. (2003) "Trust and Civic Engagement in East and West", i Gabriel Badescu \& Eric M. Uslaner (red.), Social Capital and the Transition to Democracy, London: Routledge.

Uslaner, Eric M. (2004) "Trust and Corruption”, i Johann Graf Lambsdorf, Markus Taube \& Matthias Schramm (red.), Corruption and the New Institutional Economics, London: Routledge.

Uslaner, Eric M. (2005) The Bulging Pocket and the Rule of Law: Corruption, Inequality, and Trust, paper presenterat vid konferensen "The Quality of Government: What It Is, How to Get It, Why It Matters" vid The Quality of Government Institute, Statsvetenskapliga institutionen, Göteborgs universitet, 17-I9 november 2005.

Uslaner, Eric M. (2008) Corruption, Inequality, and the Rule of Law. The Bulging Pocket makes the Easy Life, Cambridge: Cambridge University Press.

Uslaner, Eric M. \& Gabriel Badescu (2004) Making the Grade in Transition: Equality, Transparency, Trust, and Fairness, opublicerat manuskript. URL: http://papers.ssrn.com/sol3/papers.cfm?abstract_id=824486 (9 oktober 20I5) 
Uslaner, Eric M. \& Mitchell Brown (2005) "Inequality, Trust, and Civic Engagement", American Politics Research, 33, 6. DOI: http://dx.doi.org/IO.1I77/I532673X04271903

Winter, Ian (red.) (2000) Social Capital and Public Policy in Australia, Melbourne: Australian Institute of Family Studies.

Woolcock, Michael \& Deepa Narayan (200o) "Social Capital: Implications for Development Theory, Research, and Policy”, World Bank Research Observer, I5, 2. DoI: http://dx.doi.org/IO.IO93/wbro/I5.2.225

You, Jong-Sung (2005) A Comparative Study of Income Inequality, Corruption, and Social Trust: How Inequality and Corruption Reinforce Each Other and Erode Social Trust, opublicerat avhandlingsmanus, John F. Kennedy School of Government vid Harvard University.

Zak, Paul J. \& Stephen Knack (200I) "Trust and Growth", The Economic Journal, III, 470 .

DOI: http://dx.doi.org/IO.IIII/I468-0297.00609

Åberg, Rune (1989) "Distributive Mechanisms of the Welfare State - a Formal Analysis and an Empirical Application", European Sociological Review, 5, 2.

Örkény, Antal (2000) "Trends in Perceptions of Social Inequality in Hungary, 199II996”, i David S. Mason \& James R. Kluegel (red.), Marketing Democracy, Lanham: Rowman and Littlefield.

Örkény, Antal \& Mária Székelyi (2000) "Views on Social Inequality and the Role of the State: Posttransformation Trends in Eastern and Central Europe", Social Justice Research, 13, 2.

DoI: http://dx.doi.org/IO.IO23/A:I0075020080I9 


\section{Moderna klassiker}

\section{Albert O. Hirschman Sorti eller protest}

\section{Arkiv förlag}

Albert O. Hirschman visar i sitt klassiska arbete, Sorti eller protest. En fraiga om lojaliteter (Exit, Voice, and Loyalty 1970), hur fruktbart det är att kontrastera sortin, protesten och lojaliteten som olika sätt att handla inom den ekonomiska, politiska och civila sfären. I företag, politiska partier, organisationer eller nationer, i bagatellartade situationer eller livsavgörande ögonblick ställs individen ibland inför valet att lojalt acceptera, att säga ifrån och försöka påverka eller att ta konsekvenserna av en oacceptabel och ohållbar situation och dra sig ur spelet.

Arkiv förlag 2008, I92 sidor

»Läs mer om boken på www.arkiv.nu« 